\title{
Illuminating the Role of Vitamin A in Skin Innate Immunity and the Skin Microbiome: A Narrative Review
}

\author{
Fritzlaine C. Roche ${ }^{1,2}$ and Tamia A. Harris-Tryon 1,3,* \\ 1 Department of Dermatology, University of Texas Southwestern Medical Center, Dallas, TX 75390, USA; \\ fritzlaine_roche@urmc.rochester.edu \\ 2 Department of Dermatology, University of Rochester School of Medicine \& Dentistry, \\ Rochester, NY 14642, USA \\ 3 Department of Immunology, University of Texas Southwestern Medical Center, Dallas, TX 75390, USA \\ * Correspondence: tamia.harris-tryon@utsouthwestern.edu
}

check for updates

Citation: Roche, F.C.; Harris-Tryon, T.A. Illuminating the Role of Vitamin A in Skin Innate Immunity and the Skin Microbiome: A Narrative Review. Nutrients 2021, 13, 302. https://doi.org/10.3390/nu13020302

Received: 28 December 2020

Accepted: 19 January 2021

Published: 21 January 2021

Publisher's Note: MDPI stays neutral with regard to jurisdictional claims in published maps and institutional affiliations.

Copyright: (C) 2021 by the authors. Licensee MDPI, Basel, Switzerland. This article is an open access article distributed under the terms and conditions of the Creative Commons Attribution (CC BY) license (https:/ / creativecommons.org/licenses/by/ $4.0 /)$.

\begin{abstract}
Vitamin A is a fat-soluble vitamin that plays an important role in skin immunity. Deficiencies in Vitamin A have been linked to impaired immune response and increased susceptibility to skin infections and inflammatory skin disease. This narrative review summarizes recent primary evidence that elucidates the role of vitamin $\mathrm{A}$ and its derivatives on innate immune regulators through mechanisms that promote skin immunity and sustain the skin microbiome.
\end{abstract}

Keywords: vitamin A; retinoic acid; skin immunity; innate immunity; skin microbiome

\section{Introduction}

The skin is the largest epithelial organ and acts as an essential barrier between internal organs and the outer microbial world [1]. The skin functions as a barrier against diverse microbial communities through a variety of immune defense strategies. These defense strategies are in part mediated by nutrients that influence the gene expression of antimicrobial proteins and molecules that enhance skin immunity [2]. There is increasing evidence in the literature of the essential role of vitamin A and its derivatives in skin immunity. In this review, we survey current knowledge on the role of vitamin A and its metabolite, retinoic acid, in skin innate immunity and the skin microbiome through examining primary animal and human studies. Scientific studies published between 2005 and 2020 in the databases of PubMed and Google Scholar were identified using the specific search terms "vitamin A and skin innate immunity", "retinoic acid and skin innate immunity", "vitamin A and skin microbiome", "retinoic acid and skin microbiome" and "vitamin A and skin inflammation". A few key scientific studies published prior to 2005 were also included to provide a historical context to the evolving role of vitamin A on skin innate immunity and the skin microbiome.

\section{Vitamin A, Retinoids, and the Skin's Innate Immune Response}

Vitamin A is a lipid-soluble essential nutrient of the diet that modulates the immune response and maintains homeostasis of epithelial tissues and mucosa through its metabolite, retinoic acid (RA) [3]. RA controls gene expression through retinoic acid receptors (RARs), which are transcription factors expressed by the skin that mediate expression of target genes [4,5]. Deficiencies in vitamin A have been linked to an increased susceptibility to skin infection and inflammation [6,7]. This susceptibility has suggested an integral role for vitamin $\mathrm{A}$ in promoting immune function in the skin (Figure 1). 


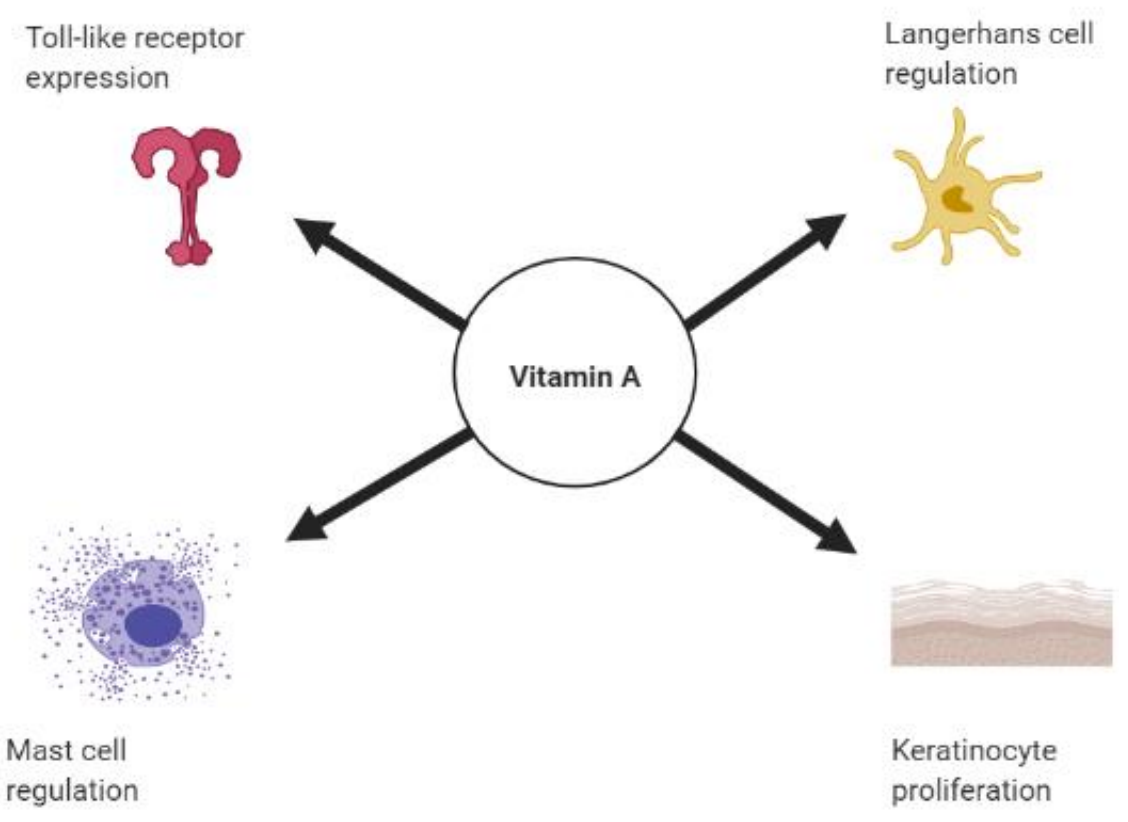

Figure 1. Role of vitamin A on skin innate immunity. Schematic diagram of the role of vitamin A on promoting toll-like receptor expression, mast cells, and Langerhans cell regulation and keratinocyte proliferation. Created with BioRender.

\subsection{Vitamin A and Toll Like Receptors}

Key components of the innate immune system in skin are toll-like receptors (TLRs) [8], which are expressed in all innate immune cells, including antigen presenting cells (APCs), epithelial cells and endothelial cells [9]. Each TLR is a pathogen recognition receptor (PRR) that responds to signals from pathogens or damaged cells and induces a pro-inflammatory immune response, through the translocation of nuclear factor-kappa B (NF- $\mathrm{kB}$ ) into the nucleus [10]. TLRs are subdivided based on their cellular localization. TLR1, TLR2, TLR4, TLR5, TLR6 and TLR11 are expressed on the plasma membrane and recognize microbial membrane lipids, lipoproteins and proteins [9]. The other group of TLRs, consisting of TLR3, TLR7, TLR8 and TLR9, are expressed on intracellular vesicles and recognize microbial nucleic acids [9].

In the skin, TLR2 and TLR3 biology is dependent on retinoic acid [11,12]. The ligand for TLR3 is double-stranded RNA (dsRNA). In skin, dsRNA that can activate TLR3 is generated by both skin damage and live viruses $[13,14]$. It has previously been shown that damaged skin activates TLR3 and induces follicular regeneration through a process known as wound-induced hair neogenesis (WIHN) $[12,13,15,16]$ (Figure 2). Emerging evidence suggests that WIHN requires both TLR3 and RA [12,17]. TLR3 induces RA synthesis and signaling, which in turn promotes follicular hair regeneration [12]. Kim et al. show in mice and human keratinocytes that dsRNA induces intrinsic RA synthesis in a TLR3-dependent manner [12]. Thus, removal of TLR3 in the $T l r 3^{-/-}$mouse model abrogates RA production and hair follicle regeneration [12]. The observation that TLR3 triggers RA synthesis and signaling to promote regeneration also implies that combining TLR3 agonists with RA could have therapeutic benefits in skin and hair regeneration.

TLR2 is also impacted by RA. Di- and tri- acylated lipoproteins-often found on Gram-negative and Gram-positive bacteria-act as ligands to TLR2 [18]. TLR2-related pathways are essential for triggering the antimicrobial activity of keratinocytes against staphylococcal infections [18-20]. Liu et al. show in primary human monocytes that treatment with all-trans retinoic acid (ATRA) down-regulates TLR2 and its co-receptor, CD14 [11]. Additionally, treatment of the monocytes with ATRA decreased TLR2-induced release of the proinflammatory cytokine, IL-6, from CD14 ${ }^{+}$monocytes by 74 percent [11]. These data suggest that agents such as ATRA that target TLR expression and function may provide new strategies for treating inflammatory dermatologic conditions. 


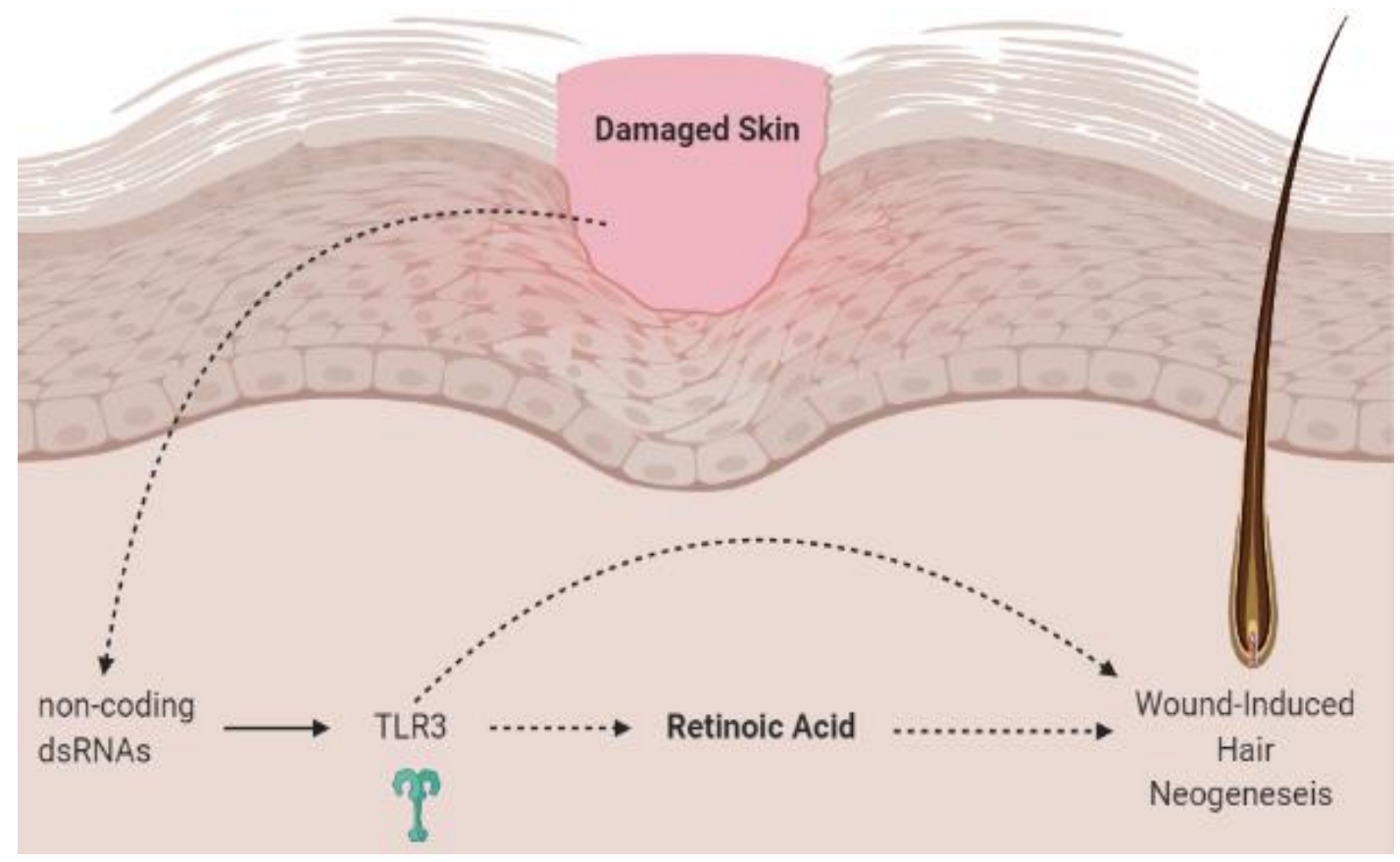

Figure 2. Wound-induced hair neogenesis. Skin injury stimulates non-coding dsRNA to activate TLR3 signaling, which triggers retinoic acid and mediates wound-induced hair neogenesis. Created with BioRender. Adapted from Kim et al. [21]. dsRNA, double-stranded RNA; TLR3, toll-like receptor 3.

\subsection{Retinoids and Keratinocytes}

Keratinocytes are epithelial cells of the skin that express PRRs that activate the immune response when exposed to pathogens [22]. The downstream signaling that results from the interaction between PRR and pathogen-association molecular patterns (PAMPs) leads to the release of proinflammatory cytokines that modulate the immune response [22,23]. It has been recognized that both vitamin A deficiency and excess can lead to abnormal epithelial keratinization [24-26] as seen in acne vulgaris and psoriasis [27,28]. There is limited understanding of the mechanism by which retinoids regulate keratinocyte cell proliferation. A few in vitro and in vivo studies have shown that retinoids modulate epidermal proliferation by exerting an anti-proliferative effect on keratinocytes [23,29] through modulation of keratinocyte differentiation [30,31], tyrosine kinase expression [26,32] and posttranslational processing of keratinocyte proteins [33]. As there is no unified understanding that explains the effect of RA on keratinocyte development, a multicomponent mechanism may best explain the therapeutic success of retinoids in treatment of hyperkeratotic skin conditions.

\subsection{Retinoic Acid and Dendritic Cells}

Dendritic cells are APCs that recognize external antigens and present them to naïve $\mathrm{T}$ cells. These cells are present in three subtypes: dermal dendritic cells, plasmacytoid dendritic cells and langerhans cells, which are the main DC subset in the epidermis [34]. Langerhans cells (LCs) are among the first dendritic cells to encounter microbial antigens [34]. In previous years, retinoids were found to contribute to LC maturation $[35,36]$. In an early study, isolation of LC from BALB/c mice treated with topical all-trans-retinoic acid, with or without ultra-violet radiation, induced an enhanced mixed epidermal cell lymphocyte reaction and enhanced allogeneic immune response [35]. A more recent study found that the development of LCs and langerin ${ }^{+}$conventional DCs, found in the dermis and other tissues, is regulated by RAR $\alpha$ in a RA-concentration-dependent manner [37]. Mice deficient in the RAR $\alpha$, due to deletion of the Rara gene, had defective LC development and failed to give rise to LCs in the skin [37]. The in vitro studies in both mice and human cells suggest that environmental influences on the RA-RAR $\alpha$ axis regulate LC develop- 
ment [37]. In hypo-RA conditions, $R A R \alpha$ promoted development of DC populations, and this was inhibited by rises in the systemic concentrations of RA [37]. The modulation of LC function by RA in these studies may explain the mechanism behind the treatment of dermatologic conditions with retinoids. However, the current knowledge on the direct effect of retinoids on DCs in the treatment of dermatologic conditions such as psoriasis is sparse and remains controversial $[38,39]$. This may be attributable to the complex involvement of various stimuli such as cytokines and ligands for pattern recognition receptors on the differentiation of DCs and variable effects on RAR types [3,40,41].

Notably, a recent investigation in a mouse model of psoriasis showed that activation of the retinoic-acid inducible-gene I (RIG-1), one of the major sensors of RNA viruses, triggers psoriasis-like skin disease through mediating endogenous IL-23 production by CD11c ${ }^{+}$ dendritic cells [42]. These findings suggest that in genetically predisposed individuals, viral infection may trigger psoriasis through the activation of TLR7, TLR8 and/or RIG-1 antiviral signaling and induction of IL-23 expression in CD11c ${ }^{+}$dendritic cells [42]. IL-23 production in dendritic cells is NFKB-dependent. Therefore, in the setting of uncontrolled IL-23 release, mutations in NFKB may impair negative regulation of its proinflammatory activity leading to psoriasis [42]. This model warrants further consideration in the context of our current understanding of the role of vitamin A on immunity, as RIG-1 expression is induced by retinoic acid. Further, deficiencies in vitamin A have been shown to compromise responses to infection and vaccination [7]. Perhaps this hampered anti-viral response in vitamin-A deficiency is partially due to deficiency in RIG-1 signaling leading to a decreased T-helper 17 (Th-17) response. Indeed, there is diminished T-helper 17 (Th-17) response observed in vivo [7] in the setting of vitamin A deficiency. Th-17 cells are elicited via the actions of multiple cytokines, including IL-23, which is produced by DCs. Thus, disturbances to the regulation of DCs by RA and RIG-1 may impart changes that modulate the adaptive immune response. Physiologic concentrations of retinoids appear to sustain Th-17 development and maintenance $[7,43,44]$. Thus, it may be the case that enhanced activation of RIG-I due to NF- $\mathrm{kB}$ mutations disrupts skin homeostasis and gives rise to a hyperactive innate immune response, leading to the inflammation seen in psoriasis.

\subsection{Vitamin A and Mast Cells}

Vitamin A and its derivatives also play a role in mast cell regulation. Connective tissue mast cells are constitutively rich in the skin [45,46]. These innate immune cells increase in number and are functionally altered in atopic dermatitis [47], psoriasis [48] and chronic urticaria [49]. These cells express high affinity IgE receptor (FceRI) and TLRs (1-4, 6, 7 and 9) that respond to various microbial products, resulting in secretion of proinflammatory cytokines in the immune response [50]. RA is commonly used for treatment of inflammatory skin conditions and may have a complex role in mast cell regulation. It has been shown that all-trans RA can act on RAR $\alpha$ in mast cells, resulting in the release of cytokines such as IL-1 $\beta$, tumor necrosis factor- $\alpha$ (TNF $\alpha$ ) and IL-8 from mast cells [51]. As shown in in vitro and in vivo studies in mice, this mechanism may be due to RA activation of Masrelated G-protein-coupled receptor-X2 (MRGPRX2), which induces mast cell degranulation, enhancing innate immunity against bacteria [52]. Since mast cells interact with T cells and are modulated by cytokines released from these adaptive cells [50], RA may modulate mast cell activity via both innate and adaptive immune processes. Vitamin A deficiency has also been shown to exacerbate extrinsic atopic dermatitis due to augmentation of Th2-mediated inflammation and mast cell activation, further supporting vitamin A as a regulator of mast cell activity [27].

\section{Vitamin A, Antimicrobial Proteins and the Skin Microbiome}

The epithelium of the skin, like that of the intestine, interfaces directly with the external environment and encounters a diversity of pathogens including bacteria, fungi and viruses [53-55]. Keratinocytes are pro-inflammatory cells of the epidermal layer of the skin that produce antimicrobial proteins (AMPs). AMPs belong to an array of protein 
families that function to rapidly kill or inactivate micro-organisms [56]. Epithelial AMPs play an essential role in preventing pathogenic invasion of the skin [56]. Amongst the several distinct AMP families that have been identified in the skin, cathelicidins, S100 proteins and $\beta$-defensins have been described [56]. Emerging research has sought to identify the role of vitamin A in AMP expression in the skin and the promotion of innate immunity against infection [2].

\subsection{Vitamin A and Resistin-Like Molecule $\alpha$}

Recent work has established that the Resistin family of proteins has anti-microbial properties [2,57]. Mouse skin expresses Resistin-like molecule $\alpha$ (RELM $\alpha)$ and Resistin. Human skin expresses the protein Resistin. Both mouse RELM $\alpha$ and human Resistin kill bacteria at low micromolar concentrations in skin (Figure 3). Retnla ${ }^{-1-}$ mice, which do not express RELM $\alpha$, are more susceptible to skin infection and have an altered skin microbiome. Interestingly, dietary vitamin A is required for RELM $\alpha$ expression in mice and mice treated with the vitamin A analog, isotretinoin, had increased expression of RELM $\alpha$ and increased resistance to infection of the skin [2]. Thus, dietary vitamin A plays an important function in regulating skin immunity.

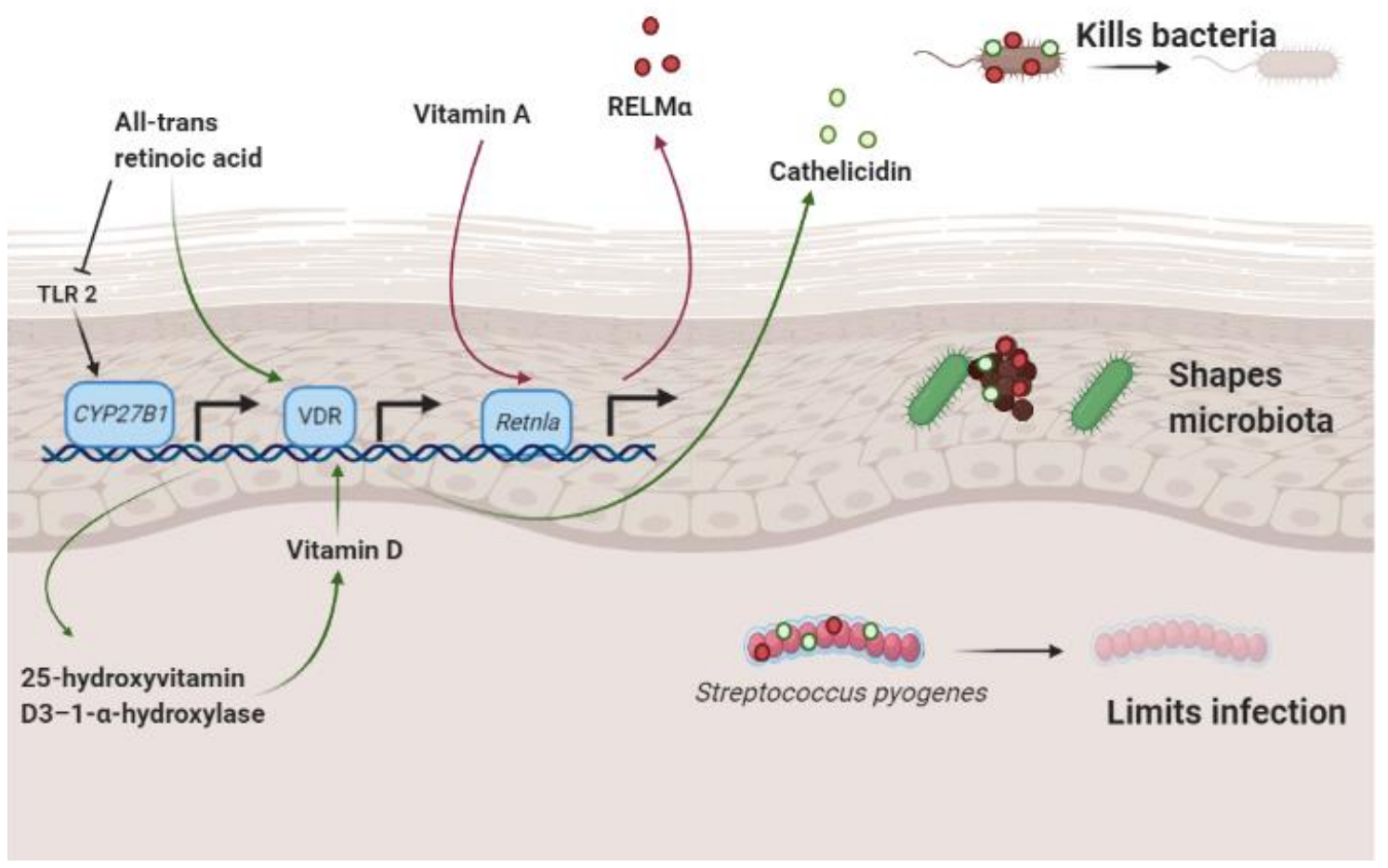

Figure 3. Schematic diagram of RELM $\alpha$ and cathelicidin involvement in skin immunity and the skin microbiome. Dietary vitamin A triggers the transcription of the Retnla gene which encodes the RELM $\alpha$ antimicrobial protein. When expressed, RELM $\alpha$ kills bacterial species that colonize the skin, shapes the resident microbiota and reduces the viability of invading pathogens such as Streptococcus pyogenes to limit infection. All-trans retinoic acid stimulates transcription of cathelicidin. When expressed, cathelicidin potentiates the immune response against microbial infection. Created in BioRender; adapted from Harris et al. [2]. RELM $\alpha$, Resistin-like molecule $\alpha$; Retnla, Resistin-like alpha precursor; CYP, cytochrome P450 family; VDR, Vitamin D receptor; TLR, toll-like receptor.

\subsection{Retinoic Acid and Cathelicidin}

Cathelicidin is an AMP that is expressed by keratinocytes, sebocytes and adipocytes in skin. In a recent study, retinoic acid enhanced cathelicidin expression in adipocytes during reactive adipogenesis in vitro and in vivo in mouse and human preadipocytes [58]. During reactive adipogenesis, dermal fibroblasts of the preadipocyte lineage undergo rapid, local proliferation and differentiation in response to bacterial infection of the skin [59]. This 
process is important in skin innate immunity as it increases the expression of cathelicidin, which enhances the immune response against bacterial infection [60] (Figure 3). Given that retinoids typically inhibit adipogenesis, the enhancement of cathelicidin expression in preadipocytes treated with RA is suggestive of a more complex immunomodulatory role of RA in the skin and the immune defense.

\subsection{Vitamin A and Staphylococcus aureus}

Prior studies have shown that vitamin A deficiency leads to a state of immunodeficiency [61]. This immunodeficient state may predispose subjects to an increased incidence of Staphylococcus aureus (S. aureus) skin infection [61-63]. There is growing evidence that S. aureus colonization $[63-65]$ and vitamin A deficiency $[27,61,66,67]$ are influential in atopic dermatitis disease pathogenesis. Subjects with atopic dermatitis have increased bacterial colonization with $S$. aureus due to a multitude of factors, including a defective innate immune response [68], and this finding correlates with their notably less diverse skin microbiome $[62,69]$. These interesting observations encourage further exploration of the regulatory role of vitamin A and its derivatives on skin immunity, the skin microbiome and the development of inflammatory skin disease.

\subsection{Vitamin A, Retinoic Acid and the Hair Microbiome}

It is well established that RA has an important role in hair growth, differentiation and regeneration [70-72]. Much less is known about the interplay of RA, hair immunity and the hair microbiome. Within the skin, the hair follicle serves as a microbial niche for bacteria [73], fungi [74] and viruses [75]. Below the bulge region of the hair follicle, the epithelium is an immune-privileged territory that is restricted from the antimicrobial activity of immune cells [76-78]. Given its immune privilege, it is possible that the hair follicle employs the actions of AMPs such as cathelicidin to maintain homeostasis of the hair microbiome [79]. Emilianov et al. show that lesional skin from patients with hidradenitis suppurativa has an increased abundance of cathelicidin in the distal outer root sheath of the affected hair follicle [79]. Given the inducing effects of RA on cathelicidin in the skin during reactive adipogenesis [58], these data suggest a similar mechanism may regulate the microbiota environment of the hair follicle. As the human hair follicle microbiome remains to be fully characterized, current understanding of the hair microbiome is best extrapolated from evidence of the skin microbiome. Thus, the role of vitamin A in the maintenance of the human hair microbiome is a challenging question that requires further primary investigations.

\section{Conclusions}

In this review, we summarize the effect of vitamin A, RA and retinoids in immune processes that promote skin immunity. These processes are intricately involved in the homeostasis of the skin microbiome and may be extrapolated to processes that regulate hair follicle immunity. Understanding the role of vitamin A and its derivatives on the innate immune system and the skin microbiome is of particular significance to translational human skin biology research and the development of therapeutic targets. Generating robust data on the mechanistic interplay of vitamin A and its derivatives on skin immunity and the skin microbiome may inform disease outcome and treatment response to agents that modulate innate immune signaling and AMP production.

Author Contributions: Conceptualization, F.C.R. and T.A.H.-T.; writing-original draft preparation, F.C.R.; writing-review and editing, T.A.H.-T.; supervision, T.A.H.-T.; funding acquisition, T.A.H.-T. All authors have read and agreed to the published version of the manuscript.

Funding: This research was funded by Dermatology Foundation Diversity Supplement Award.

Institutional Review Board Statement: Not applicable.

Informed Consent Statement: Not applicable. 
Data Availability Statement: Not applicable.

Acknowledgments: We thank the Dermatology Foundation for their support of the research grant.

Conflicts of Interest: The authors declare no conflict of interest.

\section{References}

1. Gallo, R.L. Human skin is the largest epithelial surface for interaction with microbes. J. Investig. Dermatol. 2017, 137, 1213-1214. [CrossRef] [PubMed]

2. Harris, T.A.; Gattu, S.; Propheter, D.C.; Kuang, Z.; Bel, S.; Ruhn, K.A.; Chara, A.L.; Edwards, M.; Zhang, C.; Jo, J.-H.; et al. Resistinlike molecule $\alpha$ provides Vitamin-A-dependent antimicrobial protection in the skin. Cell Host Microbe 2019, 25, 777-788.e778. [CrossRef] [PubMed]

3. Mora, J.R.; Iwata, M.; von Andrian, U.H. Vitamin effects on the immune system: Vitamins A and D take centre stage. Nat. Rev. Immunol. 2008, 8, 685-698. [CrossRef] [PubMed]

4. Idres, N.; Marill, J.; Flexor, M.A.; Chabot, G.G. Activation of retinoic acid receptor-dependent transcription by all-trans-retinoic acid metabolites and isomers. J. Biol. Chem. 2002, 277, 31491-31498. [CrossRef]

5. $\quad$ Elder, J.T.; Fisher, G.J.; Zhang, Q.Y.; Eisen, D.; Krust, A.; Kastner, P.; Chambon, P.; Voorhees, J.J. Retinoic acid receptor gene expression in human skin. J. Investig. Dermatol. 1991, 96, 425-433. [CrossRef]

6. Chen, W.; Zhao, S.; Zhu, W.; Wu, L.; Chen, X. Retinoids as an Immunity-modulator in Dermatology Disorders. Arch. Immunol. Ther. Exp. 2019, 67, 355-365. [CrossRef]

7. Hall, J.A.; Cannons, J.L.; Grainger, J.R.; Dos Santos, L.M.; Hand, T.W.; Naik, S.; Wohlfert, E.A.; Chou, D.B.; Oldenhove, G.; Robinson, M.; et al. Essential role for retinoic acid in the promotion of CD4(+) T cell effector responses via retinoic acid receptor alpha. Immunity 2011, 34, 435-447. [CrossRef]

8. Silvestre, M.C.; Sato, M.N.; Reis, V. Innate immunity and effector and regulatory mechanisms involved in allergic contact dermatitis. An. Bras. Dermatol. 2018, 93, 242-250. [CrossRef]

9. Kawai, T.; Akira, S. The role of pattern-recognition receptors in innate immunity: Update on Toll-like receptors. Nat. Immunol. 2010, 11, 373-384. [CrossRef]

10. Vijay, K. Toll-like receptors in immunity and inflammatory diseases: Past, present, and future. Int. Immunopharmacol. 2018, 59, 391-412. [CrossRef]

11. Liu, P.T.; Krutzik, S.R.; Kim, J.; Modlin, R.L. Cutting edge: All-trans retinoic acid down-regulates TLR2 expression and function. J. Immunol. 2005, 174, 2467-2470. [CrossRef] [PubMed]

12. Kim, D.; Chen, R.; Sheu, M.; Kim, N.; Kim, S.; Islam, N.; Wier, E.M.; Wang, G.; Li, A.; Park, A.; et al. Noncoding dsRNA induces retinoic acid synthesis to stimulate hair follicle regeneration via TLR3. Nat. Commun. 2019, 10, 2811. [CrossRef] [PubMed]

13. Nelson, A.M.; Reddy, S.K.; Ratliff, T.S.; Hossain, M.Z.; Katseff, A.S.; Zhu, A.S.; Chang, E.; Resnik, S.R.; Page, C.; Kim, D.; et al. dsRNA released by tissue damage activates TLR3 to drive skin regeneration. Cell Stem Cell 2015, 17, 139-151. [CrossRef] [PubMed]

14. Jensen, S.; Thomsen, A.R. Sensing of RNA Viruses: A review of innate immune receptors involved in recognizing RNA virus invasion. J. Virol. 2012, 86, 2900-2910. [CrossRef] [PubMed]

15. Lai, Y.; Di Nardo, A.; Nakatsuji, T.; Leichtle, A.; Yang, Y.; Cogen, A.L.; Wu, Z.R.; Hooper, L.V.; Schmidt, R.R.; von Aulock, S.; et al. Commensal bacteria regulate Toll-like receptor 3-dependent inflammation after skin injury. Nat. Med. 2009, 15, 1377-1382. [CrossRef] [PubMed]

16. Bernard, J.J.; Cowing-Zitron, C.; Nakatsuji, T.; Muehleisen, B.; Muto, J.; Borkowski, A.W.; Martinez, L.; Greidinger, E.L.; Yu, B.D.; Gallo, R.L. Ultraviolet radiation damages self noncoding RNA and is detected by TLR3. Nat. Med. 2012, 18, 1286-1290. [CrossRef]

17. Canino, C.; Luo, Y.; Marcato, P.; Blandino, G.; Pass, H.I.; Cioce, M. A STAT3-NFkB/DDIT3/CEBP $\beta$ axis modulates ALDH1A3 expression in chemoresistant cell subpopulations. Oncotarget 2015, 6, 12637-12653. [CrossRef]

18. Strunk, T.; Power Coombs, M.R.; Currie, A.J.; Richmond, P.; Golenbock, D.T.; Stoler-Barak, L.; Gallington, L.C.; Otto, M.; Burgner, D.; Levy, O. TLR2 mediates recognition of live Staphylococcus epidermidis and clearance of bacteremia. PLoS ONE 2010, 5, e10111. [CrossRef]

19. Talreja, D.; Singh, P.K.; Kumar, A. In vivo role of TLR2 and MyD88 signaling in eliciting innate immune responses in staphylococcal endophthalmitis. Investig. Ophthalmol. Vis. Sci. 2015, 56, 1719-1732. [CrossRef]

20. Mullaly, S.C.; Kubes, P. The role of TLR2 in vivo following challenge with Staphylococcus aureus and prototypic ligands. J. Immunol. 2006, 177, 8154-8163. [CrossRef]

21. Kim, D.; Garza, L.A. Hypothesis: Wound-induced TLR3 activation stimulates endogenous retinoic acid synthesis and signalling during regeneration. Exp. Dermatol. 2019, 28, 450-452. [CrossRef] [PubMed]

22. Krutzik, S.R.; Tan, B.; Li, H.; Ochoa, M.T.; Liu, P.T.; Sharfstein, S.E.; Graeber, T.G.; Sieling, P.A.; Liu, Y.J.; Rea, T.H.; et al. TLR activation triggers the rapid differentiation of monocytes into macrophages and dendritic cells. Nat. Med. 2005, 11, 653-660. [CrossRef] [PubMed]

23. Popadic, S.; Ramic, Z.; Medenica, L.; Mostarica Stojkovic, M.; Trajković, V.; Popadic, D. Antiproliferative effect of vitamin A and $\mathrm{D}$ analogues on adult human keratinocytes in vitro. Skin Pharmacol. Physiol. 2008, 21, 227-234. [CrossRef] [PubMed]

24. Wolbach, S.B.; Howe, P.R. Tissue changes following deprivation of fat-soluble a vitamin. J. Exp. Med. 1925, 42, 753-777. [CrossRef] [PubMed] 
25. Christophers, E.; Wolff, H.H. Effects of vitamin A acid in skin: In vivo and in vitro studies. Acta Derm. Venereol. Suppl. 1975, 74, $42-49$.

26. Rittié, L.; Varani, J.; Kang, S.; Voorhees, J.J.; Fisher, G.J. Retinoid-induced epidermal hyperplasia is mediated by epidermal growth factor receptor activation via specific induction of its ligands heparin-binding EGF and amphiregulin in human skin in vivo. J. Investig. Dermatol. 2006, 126, 732-739. [CrossRef]

27. Yang, H.; Chen, J.S.; Zou, W.J.; Tan, Q.; Xiao, Y.Z.; Luo, X.Y.; Gao, P.; Fu, Z.; Wang, H. Vitamin A deficiency exacerbates extrinsic atopic dermatitis development by potentiating type 2 helper $\mathrm{T}$ cell-type inflammation and mast cell activation. Clin. Exp. Allergy 2020. [CrossRef]

28. Balato, A.; Schiattarella, M.; Lembo, S.; Mattii, M.; Prevete, N.; Balato, N.; Ayala, F. Interleukin-1 family members are enhanced in psoriasis and suppressed by vitamin D and retinoic acid. Arch. Dermatol. Res. 2013, 305, 255-262. [CrossRef]

29. Jean, J.; Soucy, J.; Pouliot, R. Effects of retinoic acid on keratinocyte proliferation and differentiation in a psoriatic skin model. Tissue Eng. Part A 2011, 17, 1859-1868. [CrossRef]

30. Schroeder, M.; Zouboulis, C.C. All-trans-retinoic acid and 13-cis-retinoic acid: Pharmacokinetics and biological activity in different cell culture models of human keratinocytes. Horm. Metab. Res. 2007, 39, 136-140. [CrossRef]

31. Masgrau-Peya, E.; Salomon, D.; Saurat, J.H.; Meda, P. In vivo modulation of connexins 43 and 26 of human epidermis by topical retinoic acid treatment. J. Histochem. Cytochem. 1997, 45, 1207-1215. [CrossRef]

32. Stoll, S.W.; Elder, J.T. Retinoid regulation of heparin-binding EGF-like growth factor gene expression in human keratinocytes and skin. Exp. Dermatol. 1998, 7, 391-397. [CrossRef] [PubMed]

33. Eichner, R. Epidermal effects of retinoids: In vitro studies. J. Am. Acad. Dermatol. 1986, 15, 789-797. [CrossRef]

34. Nestle, F.O.; Di Meglio, P.; Qin, J.-Z.; Nickoloff, B.J. Skin immune sentinels in health and disease. Nat. Rev. Immunol. 2009, 9, 679-691. [CrossRef] [PubMed]

35. Dunlop, K.J.; Halliday, G.M.; Barnetson, R.S.C. All-trans retinoic acid induces functional maturation of epidermal Langerhans cells and protects their accessory function from ultraviolet radiation. Exp. Dermatol. 1994, 3, 204-211. [CrossRef] [PubMed]

36. Ho, K.K.; Halliday, G.M.; Barnetson, R.S. Topical and oral retinoids protect Langerhans' cells and epidermal Thy-1+ dendritic cells from being depleted by ultraviolet radiation. Immunology 1991, 74, 425-431.

37. Hashimoto-Hill, S.; Friesen, L.; Park, S.; Im, S.; Kaplan, M.H.; Kim, C.H. RAR $\alpha$ supports the development of Langerhans cells and langerin-expressing conventional dendritic cells. Nat. Commun. 2018, 9, 3896. [CrossRef] [PubMed]

38. Irla, N.; Navarini, A.A.; Yawalkar, N. Alitretinoin abrogates innate inflammation in palmoplantar pustular psoriasis. Br. J. Dermatol. 2012, 167, 1170-1174. [CrossRef]

39. Kraus, L.F.; Scheurmann, N.; Frenzel, D.F.; Tasdogan, A.; Weiss, J.M. 9-cis-Retinoic acid induces a distinct regulatory dendritic cell phenotype that modulates murine delayed-type allergy. Contact Dermat. 2018, 78, 41-54. [CrossRef]

40. Nagy, L.; Szanto, A.; Szatmari, I.; Széles, L. Nuclear hormone receptors enable macrophages and dendritic cells to sense their lipid environment and shape their immune response. Physiol. Rev. 2012, 92, 739-789. [CrossRef]

41. Manicassamy, S.; Ravindran, R.; Deng, J.; Oluoch, H.; Denning, T.L.; Kasturi, S.P.; Rosenthal, K.M.; Evavold, B.D.; Pulendran, B. Toll-like receptor 2-dependent induction of vitamin A-metabolizing enzymes in dendritic cells promotes T regulatory responses and inhibits autoimmunity. Nat. Med. 2009, 15, 401-409. [CrossRef] [PubMed]

42. Zhu, H.; Lou, F.; Yin, Q.; Gao, Y.; Sun, Y.; Bai, J.; Xu, Z.; Liu, Z.; Cai, W.; Ke, F.; et al. RIG-I antiviral signaling drives interleukin-23 production and psoriasis-like skin disease. EMBO Mol. Med. 2017, 9, 589-604. [CrossRef] [PubMed]

43. Cha, H.R.; Chang, S.Y.; Chang, J.H.; Kim, J.O.; Yang, J.Y.; Kim, C.H.; Kweon, M.N. Downregulation of Th17 cells in the small intestine by disruption of gut flora in the absence of retinoic acid. J. Immunol. 2010, 184, 6799-6806. [CrossRef] [PubMed]

44. Wang, C.; Kang, S.G.; HogenEsch, H.; Love, P.E.; Kim, C.H. Retinoic acid determines the precise tissue tropism of inflammatory Th17 cells in the intestine. J. Immunol. 2010, 184, 5519-5526. [CrossRef] [PubMed]

45. Dwyer, D.F.; Barrett, N.A.; Austen, K.F.; Immunological Genome Project Consortium. Expression profiling of constitutive mast cells reveals a unique identity within the immune system. Nat. Immunol. 2016, 17, 878-887. [CrossRef]

46. Babina, M.; Guhl, S.; Artuc, M.; Trivedi, N.N.; Zuberbier, T. Phenotypic variability in human skin mast cells. Exp. Dermatol. 2016, 25, 434-439. [CrossRef]

47. Kawakami, T.; Ando, T.; Kimura, M.; Wilson, B.S.; Kawakami, Y. Mast cells in atopic dermatitis. Curr. Opin. Immunol. 2009, 21, 666-678. [CrossRef]

48. Harvima, I.T.; Nilsson, G.; Suttle, M.M.; Naukkarinen, A. Is there a role for mast cells in psoriasis? Arch. Dermatol. Res. 2008, 300, 461-478. [CrossRef]

49. Ferrer, M.; Kaplan, A.P. Progress and challenges in the understanding of chronic urticaria. Allergy Asthma Clin. Immunol. 2007, 3, 31-35. [CrossRef]

50. Abraham, S.N.; St John, A.L. Mast cell-orchestrated immunity to pathogens. Nat. Rev. Immunol. 2010, 10, 440-452. [CrossRef]

51. Babina, M.; Artuc, M.; Guhl, S.; Zuberbier, T. Retinoic acid negatively impacts proliferation and MC(TC) specific attributes of human skin derived mast cells, but reinforces allergic stimulability. Int. J. Mol. Sci. 2017, 18, 525. [CrossRef] [PubMed]

52. Arifuzzaman, M.; Mobley, Y.R.; Choi, H.W.; Bist, P.; Salinas, C.A.; Brown, Z.D.; Chen, S.L.; Staats, H.F.; Abraham, S.N. MRGPRmediated activation of local mast cells clears cutaneous bacterial infection and protects against reinfection. Sci. Adv. 2019, 5, eaav0216. [CrossRef] [PubMed] 
53. Grice, E.A.; Kong, H.H.; Renaud, G.; Young, A.C.; Bouffard, G.G.; Blakesley, R.W.; Wolfsberg, T.G.; Turner, M.L.; Segre, J.A. A diversity profile of the human skin microbiota. Genome Res. 2008, 18, 1043-1050. [CrossRef] [PubMed]

54. Duerkop, B.A.; Hooper, L.V. Resident viruses and their interactions with the immune system. Nat. Immunol. 2013, 14, 654-659. [CrossRef] [PubMed]

55. Foulongne, V.; Sauvage, V.; Hebert, C.; Dereure, O.; Cheval, J.; Gouilh, M.A.; Pariente, K.; Segondy, M.; Burguière, A.; Manuguerra, J.C.; et al. Human skin microbiota: High diversity of DNA viruses identified on the human skin by high throughput sequencing. PLoS ONE 2012, 7, e38499. [CrossRef] [PubMed]

56. Gallo, R.L.; Hooper, L.V. Epithelial antimicrobial defence of the skin and intestine. Nat. Rev. Immunol. 2012, 12, 503-516. [CrossRef] [PubMed]

57. Propheter, D.C.; Chara, A.L.; Harris, T.A.; Ruhn, K.A.; Hooper, L.V. Resistin-like molecule $\beta$ is a bactericidal protein that promotes spatial segregation of the microbiota and the colonic epithelium. Proc. Natl. Acad. Sci. USA 2017, 114, 11027-11033. [CrossRef]

58. Liggins, M.C.; Li, F.; Zhang, L.J.; Dokoshi, T.; Gallo, R.L. Retinoids enhance the expression of cathelicidin antimicrobial peptide during reactive dermal adipogenesis. J. Immunol. 2019, 203, 1589-1597. [CrossRef]

59. Zhang, L.J.; Chen, S.X.; Guerrero-Juarez, C.F.; Li, F.; Tong, Y.; Liang, Y.; Liggins, M.; Chen, X.; Chen, H.; Li, M.; et al. Age-related loss of innate immune antimicrobial function of dermal fat is mediated by transforming growth factor beta. Immunity 2019, 50, 121-136.e125. [CrossRef]

60. Zhang, L.J.; Guerrero-Juarez, C.F.; Hata, T.; Bapat, S.P.; Ramos, R.; Plikus, M.V.; Gallo, R.L. Innate immunity. Dermal adipocytes protect against invasive Staphylococcus aureus skin infection. Science 2015, 347, 67-71. [CrossRef]

61. Wiedermann, U.; Tarkowski, A.; Bremell, T.; Hanson, L.A.; Kahu, H.; Dahlgren, U.I. Vitamin A deficiency predisposes to Staphylococcus aureus infection. Infect. Immun. 1996, 64, 209-214. [CrossRef] [PubMed]

62. Paller, A.S.; Kong, H.H.; Seed, P.; Naik, S.; Scharschmidt, T.C.; Gallo, R.L.; Luger, T.; Irvine, A.D. The microbiome in patients with atopic dermatitis. J. Allergy Clin. Immunol. 2019, 143, 26-35. [CrossRef] [PubMed]

63. Totté, J.E.; van der Feltz, W.T.; Hennekam, M.; van Belkum, A.; van Zuuren, E.J.; Pasmans, S.G. Prevalence and odds of Staphylococcus aureus carriage in atopic dermatitis: A systematic review and meta-analysis. Br. J. Dermatol. 2016, 175, 687-695. [CrossRef] [PubMed]

64. Yamazaki, Y.; Nakamura, Y.; Núñez, G. Role of the microbiota in skin immunity and atopic dermatitis. Allergol. Int. 2017, 66, 539-544. [CrossRef]

65. Kobayashi, T.; Glatz, M.; Horiuchi, K.; Kawasaki, H.; Akiyama, H.; Kaplan, D.H.; Kong, H.H.; Amagai, M.; Nagao, K. Dysbiosis and staphylococcus aureus colonization drives inflammation in atopic dermatitis. Immunity 2015, 42, 756-766. [CrossRef]

66. Xiang, J.; Wang, H.; Li, T. Comorbidity of Vitamin A and Vitamin D deficiency exacerbates the severity of atopic dermatitis in children. Dermatology 2019, 235, 196-204. [CrossRef]

67. Lucas, R.; Mihály, J.; Lowe, G.M.; Graham, D.L.; Szklenar, M.; Szegedi, A.; Töröcsik, D.; Rühl, R. Reduced carotenoid and retinoid concentrations and altered lycopene isomer ratio in plasma of atopic dermatitis patients. Nutrients 2018, 10, 1390. [CrossRef]

68. Boguniewicz, M.; Leung, D.Y.M. Atopic dermatitis: A disease of altered skin barrier and immune dysregulation. Immunol. Rev. 2011, 242, 233-246. [CrossRef]

69. Kong, H.H.; Oh, J.; Deming, C.; Conlan, S.; Grice, E.A.; Beatson, M.A.; Nomicos, E.; Polley, E.C.; Komarow, H.D.; Program, N.C.S.; et al. Temporal shifts in the skin microbiome associated with disease flares and treatment in children with atopic dermatitis. Genome Res. 2012, 22, 850-859. [CrossRef]

70. Bergfeld, W.F. Retinoids and hair growth. J. Am. Acad. Dermatol. 1998, 39, S86-S89. [CrossRef]

71. Sharma, A.; Goren, A.; Dhurat, R.; Agrawal, S.; Sinclair, R.; Trüeb, R.M.; Vañó-Galván, S.; Chen, G.; Tan, Y.; Kovacevic, M.; et al. Tretinoin enhances minoxidil response in androgenetic alopecia patients by upregulating follicular sulfotransferase enzymes. Dermatol. Ther. 2019, 32, e12915. [CrossRef] [PubMed]

72. Terezakis, N.K.; Bazzano, G.S. Retinoids: Compounds important to hair growth. Clin. Dermatol. 1988, 6, 129-131. [CrossRef]

73. Ring, H.C.; Thorsen, J.; Saunte, D.M.; Lilje, B.; Bay, L.; Riis, P.T.; Larsen, N.; Andersen, L.O.; Nielsen, H.V.; Miller, I.M.; et al. The follicular skin microbiome in patients with hidradenitis suppurativa and healthy controls. JAMA Dermatol. 2017, 153, 897-905. [CrossRef] [PubMed]

74. Park, T.; Kim, H.J.; Myeong, N.R.; Lee, H.G.; Kwack, I.; Lee, J.; Kim, B.J.; Sul, W.J.; An, S. Collapse of human scalp microbiome network in dandruff and seborrhoeic dermatitis. Exp. Dermatol. 2017, 26, 835-838. [CrossRef]

75. Hall, J.B.; Cong, Z.; Imamura-Kawasawa, Y.; Kidd, B.A.; Dudley, J.T.; Thiboutot, D.M.; Nelson, A.M. Isolation and identification of the follicular microbiome: Implications for acne research. J. Investig. Dermatol. 2018, 138, 2033-2040. [CrossRef]

76. Paus, R.; Bulfone-Paus, S.; Bertolini, M. Hair follicle immune privilege revisited: The key to alopecia areata management. J. Investig. Dermatol. Symp. Proc. 2018, 19, S12-S17. [CrossRef]

77. Muneeb, F.; Hardman, J.A.; Paus, R. Hair growth control by innate immunocytes: Perifollicular macrophages revisited. Exp. Dermatol. 2019, 28, 425-431. [CrossRef]

78. Pratt, C.H.; King, L.E., Jr.; Messenger, A.G.; Christiano, A.M.; Sundberg, J.P. Alopecia areata. Nat. Rev. Dis. Primers 2017, 3. [CrossRef]

79. Emelianov, V.U.; Bechara, F.G.; Gläser, R.; Langan, E.A.; Taungjaruwinai, W.M.; Schröder, J.M.; Meyer, K.C.; Paus, R. Immunohistological pointers to a possible role for excessive cathelicidin (LL-37) expression by apocrine sweat glands in the pathogenesis of hidradenitis suppurativa/acne inversa. Br. J. Dermatol. 2012, 166, 1023-1034. [CrossRef] 